\title{
On Optimizing the Procedure of Citizens Reception by Members of RF State Duma
}

\author{
Vladislav G. Soukhovolsky ${ }^{\mathrm{a}}$, \\ Alexander M. Shelekhov ${ }^{\mathrm{b}}$ and Maxim A. Karpov** \\ a Siberian Federal University \\ 79 Svobodny, Krasnoyarsk, 660041, Russia \\ ${ }^{b}$ Tver State University \\ 33 Zhelyabova Str., Tver, 170100, Russia \\ c Ivanovo State Power University \\ 34 Rabfakovskaya Str., Ivanovo, 153003, Russia
}

Received 10.01.2016, received in revised form 26.08.2016, accepted 23.10.2016

The public reception by United Russia faction in the State Duma of the Russian Federation and the optimization problem of citizens' reception are regarded as the tasks of Queueing Theory (QT). From the point of view of QT, a Member of Parliament (MP) is seen as a "device" that serves the incoming request. The simplest queuing system M/M/1 includes a device (MP) and stream of citizens' requests, which displays certain intensity. The different versions of the reception guidelines are considered in the framework of $Q T$ as different service disciplines. The effectiveness of the citizens' reception by State Duma MP can be calculated for different service disciplines. Such assessments allow defining the system of personal reception, being optimal for both citizens and MPs.

Keywords: citizens, deputies, reception, optimization, model, queueing theory.

The work is supported by RFBR (grant № 13-07-00564-a).

DOI: 10.17516/1997-1370-2016-9-12-3015-3024.

Research area: law, politology.

\section{Introduction}

At the start of Russian parliamentary system the working procedure in the State Duma of the Russian Empire did not include reception of citizens by deputies or taking their complaints for consideration (Zakonodatel'nye..., 2010). Evidently, the specific character of modern Russian parliamentary practice comes from the practice of Soviets of all levels in the USSR, and it lies in the fact that the RF State Duma procedure rules include reception of citizens by deputies (Federal'nyi.., 1994; Federal'nyi.., 2006).

However, these rules limit the power of the deputies' interference in certain cases, though on the whole they neither limit the objects of the citizens' applications, nor specify the procedure

(C) Siberian Federal University. All rights reserved

* Corresponding author E-mail address: soukhovolsky@yandex.ru; amshelekhov@rambler.ru; max@3dlightning.net 
of their reception, or determine the order of reception. Working out the procedure of citizens' reception is very important, as it predesignates the atmosphere of hearing as well as the results of the applications' consideration.

In this view, we undertake the task of creating most favorable procedure rules for reception of citizens by Members of the RF State Duma. Optimality of the rules can be characterized by different factors. First, it is desirable for a citizen sending a request to a Member of the RF State Duma (MP) to be received within a reasonable time (for non-residents of Moscow it should not exceed 2 or 3 days), and the time for the request proceeding should not exceed some reasonable time limit (for example, 2 or 3 weeks). Second, the procedure rules must be made up in the way to avoid overloading the deputies and their assistants with citizens' requests to be considered, so they need to be distributed for consideration evenly. Third, for the requests to get a qualified assessment they must be considered by a deputy competent in the subject. And finally, preferably a request is to be considered by a deputy from the same region as the applicant (such deputies are bound to appear in the RF State Duma after the coming elections).

However, it is clear that to optimize the reception procedure taking into account all the conditions stated above is hardly possible. We have shown that the number of applications from residents of Moscow and Moscow Region in 2012-2013 season was about half of the total number of applications. If we oblige the deputies to speak to people only from their region, it will mean overloading the deputies from Moscow and Moscow Region. On the other hand, if some region is represented in the State Duma by one or two MPs, they and their assistants will have to be highly qualified in all subjects the citizens are interested in. Achieving such universalism will be quite hard, if not impossible.
In this connection there arises the task of search for a compromise and constructing a certain set of procedure rules that will allow satisfying the optimality conditions.

In the present paper the problem of optimizing the citizens' reception is regarded as a task of Queueing Theory (QT). QT is widely used in analyzing and solving various problems arising in different areas - from marketing to servers operation in computer nets (Saati, 2010). QT deals with a system including a certain device (service instrument) and a stream of claims to be served coming in to the device (Kleinrock, 1979, Gnedenko, Kovalenko, 2007). The tasks of QT are finally reduced to performance evaluation from the point of view of service cost minimization and minimization of time required for the service. An MP can be regarded from QT viewpoint as a specific "device" serving the coming in claims. As for different variants of the procedure rules within the framework of QT, they can be interpreted as different service policies.

\section{Theoretical Framework}

\section{Analysis Objects and Techniques}

We will regard the work of United Russia faction reception office in the RF State Duma as an analysis object. The procedure of receiving citizens includes a preliminary expert interview with a person seeking reception, considering the possibility (by the procedure rules of the State Duma) to accept the claim by an MP and choosing an appropriate MP for the following reception. As a rule, having come to the preliminary reception, some citizens are recommended to apply to other organizations (such as courts, etc.) if the problems of the claimers lie beyond the competence of the State Duma MPs. The law does not allow a deputy to interfere directly in the work of agencies of investigation, investigation officers and courts. Nevertheless, it is impossible to forbid citizens to apply to deputies. 
We will take the process of the citizens' reception by one MP for the task of QT and use it for the base model. Such a situation can be classified as the simplest queueing system (QS) the so-called QS M/M/1, including one device (the MP) and the stream of claims (citizens' applications) coming in for service with certain intensity $\lambda$. The claim can be proceeded or declared inadmissible for some reasons.

If at the moment of a claim coming the device is busy with proceeding another claim, the claim enters the storage and waits for the device to get free and manage it. In the simplest case, the storage capacity and waiting time are supposed to be unlimited. If the storage contains several claims, the queue of their serving is determined by the concept FIFO (First In, First Out). Each claim stays in the QS for some time including the time of serving waiting (that is, standing in the queue) and the time of serving needed by a "device".

Claim management lasts on average $\tau=\frac{1}{\mu}$ time units ( $\mu$ being intensity of serving). Optimization of the QS consists in serving a maximum number of claims while minimizing the total time of the claim being in the QS (Saati, 2010).

Suppose the average time $\tau$ needed for the deputy to consider the coming in claim does not depend on the subject and complexity of the claim, and the values of intensities of claims' stream and serving $\mu=1 / \tau$ have the Poisson distribution. Then the total number $N$ of claims in the system is given by Little's formula (Kleinrock, 1979):

$$
N=\lambda T .
$$

It follows from (1) that when the intensity of claims stream is $\lambda$, the efficiency of the QS will depend on the average time $T$ the claim stays in the QS. If we present the time $T$, during which the claim stays in the QS, as the sum of the time
$\mathrm{T}_{0}$ of waiting for serving and time $\tau$ of serving itself, the total time $T$ of the claim in the QS will be minimal if $T \rightarrow \tau$. Indeed, it is impossible to consider an application immediately so that $\tau \rightarrow$ 0 but it is possible to reduce the time of waiting for the claim to be considered to minimum and to try to organize the immediate reception so that $T_{0} \rightarrow 0$.

The average time $T$ of the claim in the QS depends on the values of the quantities $\lambda$ and $\mu$ (Saati, 2010):

$$
T=\frac{1 / \mu}{1-\rho},
$$

where $\rho=\frac{\lambda}{\mu}$.

The relation $\rho=\frac{\lambda}{\mu}$ is an important characteristic of the QS. For the effective work of the QS there must be the condition $\lambda<\mu$. If $\lambda \rightarrow \mu$, we have $T \rightarrow \infty$, that is, the time of the claim in the QS can be arbitrarily long.

If reception is held by one MP and the stream of claims is large, waiting for the moment when deputies or their assistants will have time to analyze the request, or waiting for reception by the MP (in case the visitor insists on it) can take a long time and then $T \gg \tau$. Suppose the average value of $\mu=\mu_{0}$ does not change, then with the increasing intensity $\lambda$ of the stream of applicants to this only deputy, sooner or later we will have $\frac{\lambda}{\mu_{0}} \rightarrow 1$ and then the time of the claim in the QS - T $\rightarrow \infty$ (Kleinrock, 1979). In this case the QS is said to be overfilled and the claims cannot be managed within limited time.

In the above situation there are several possible decisions. Certainly, it is unfeasible to reduce the time $\tau$ of serving one claim. However, it is likely to make the number of serving devices larger, that is, to involve $k$ more deputies in 
the citizens' reception. From the standpoint of QT, it means transition to using QS $\mathrm{M} / \mathrm{M} / k$. Undoubtedly, when the number $n$ of serving devices is great, the average time $T$ of a claim in QS will tend to $\tau$. However, in this case the total cost of serving devices may greatly increase and such a service policy will be extremely wasteful from the point of view of QS functioning, though comfortable for the visitors.

\section{Service Policies}

Potentially it is possible to use different service policies in reception. With random service policy the incoming claim enters for service and goes to a randomly chosen "device" out of those not being busy at the moment with proceeding a previous claim. However, with this service policy a "lazy" MP will try to delay the process of considering the claim received as the longer the claim is being served the fewer new claims the MP will have to manage. On the contrary, the load on active and efficiently working MPs will become greater. Thus, this type of service is inequitable.

We suppose that using random service policy it is necessary to introduce an additional procedure of distributing applications to be considered that will guarantee a relatively equal load on all serving "devices". With such an additional procedure all "devices" can be initially ordered in some way (for example, by last names in alphabetic order), and the applications will successively come in for service to the deputies starting with the first one on the ordered list. In this case the intensity of the claims stream in some rather long time interval will be about the same with all the deputies and will be equal to $\lambda / m$ (where $m$ is the number of deputies serving the stream of visitors). However, if the serving time is different among different "devices" (it is quite possible, as there are no identical deputies or deputies' "teams"), the average serving time of a certain "device" will be substantially longer than of the others. In this case receiving a claim by such a slow "device" will lead to the increased serving time and for such deputy the relation $\frac{\lambda / m}{\mu(i)}$ will approach 1, the "device" will be "overfilled" and serving time will increase indefinitely (we can call it the "shelving" syndrome).

\section{Object Service Policy}

The character and specific nature of service is usually not described in QT. All incoming claims are supposed to be uniform and can be served by any "device". However, the situation is different with considering citizens' applications. The spectrum of objects of the applications is wide and includes various topics. The object classification currently used in receiving citizens in the State Duma United Russia faction is given in Fig. 1. We can assume that one deputy and his/her assistants are not experts in all subjects given in Fig. 1, then it is possible that in some cases when a deputy or his/her assistants are not qualified enough, the service time will increase or the service will be inexpert. But the visitor is unlikely to know about it and he/she will take further steps in accordance with the deputy's recommendations.

\section{Territorial Service Policy}

In this case a claim coming in from a certain region is served only by deputies elected from this very region. With this type of policy the intensity of the claims stream to be served by a separate "device" will be directly proportional to the number of voters in the region and their activity. It should be noted that with this service policy the deputies are elected by the party list and not by the region, and thus they will be set free from the necessity to receive citizens (or 


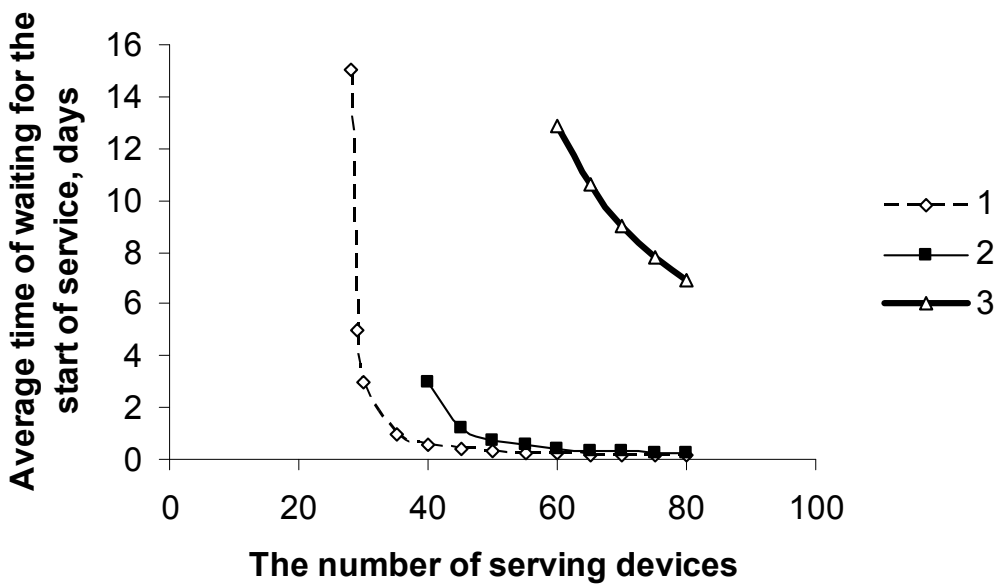

Fig. 1. The average time of waiting for the start of serving, with $\lambda=110$ applications per month; $1-$ intensity of $\mu=4$ applications per month; 2 - intensity of $\mu=3$ applications per month; 3 - intensity of $\mu=2$ applications per month

will be devoid of the right to receive citizens it will depend on how one sees the problem). Definitely, if the number of the deputies elected to the State Duma by the party list is not large, the problem can be neglected and the small number of deputies will be set free from participation in receiving citizens - that is, in case the given type of service policy is chosen.

\section{Results and Discussion}

In our analysis we use the data about previously collected and analyzed citizens' applications to the RF State Duma United Russia faction office (Soukhovolsky et al., 2014) as the document base for the research.

During 10 months of the 2012-2013 season there applied 1,093 citizens. Thus, the intensity of application $\lambda$ is 110 people per month. As it was mentioned above, the efficiency of the QS depends on the service intensity and the number of service "devices". Assume that a separate deputy can serve one application per week on average. Then $\mu=4$ people per month. If the reception is held by one deputy, $\rho=\lambda / \mu=110 / 4=$ $=27.5>>1$ and such a QS is overfilled and cannot operate. For the QS to operate, it is necessary to use $n$ separate devices. Then the time $T$ of a claim inside the system will be equal to

$$
T=\frac{1 / \mu}{1-\frac{\lambda}{n \mu}} \text {. }
$$

Let us set a psychologically acceptable average time an application stays inside the system. Assume that getting an answer within two weeks will be quite acceptable. Then, substituting $T=0.5 \mathrm{in}$ (3), with the above proposed values of $\lambda$ and $\mu$ we find the number $n$ of deputies necessary to consider the claims within two weeks:

$$
0.5=\frac{1 / 4}{1-\frac{110}{4 n}} \text { or } n=5 \text { deputies. }
$$

The time required to serve an application can be presented as the sum of the time $T_{1}$ of waiting for the start of the service and the time $T_{2}$ of the service proper (the application's analysis and preparing the answer). The time $T_{1}=0$, if at the moment of a visitor's coming to the office there is at least one free deputy among those considering applications. Otherwise, it is necessary to wait 


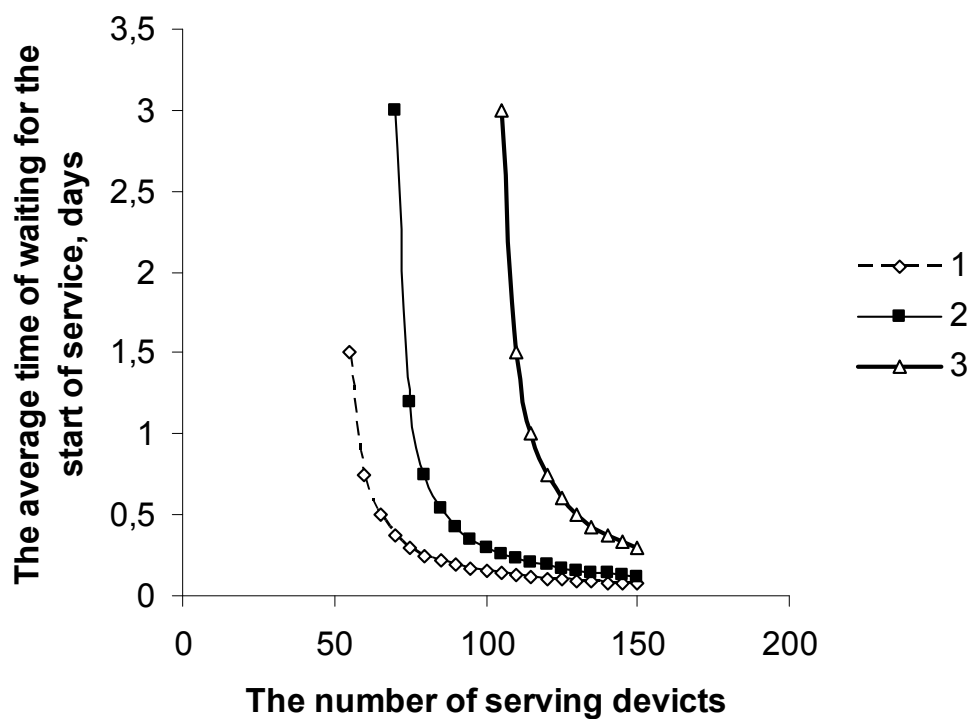

Fig, 2. The average time of waiting for the start of serving with $\lambda=110$ applications per month; $1-$ intensity of $\mu=4$ applications per month; 2 - intensity of $\mu=3$ applications per month; 3 - intensity of $\mu=2$ applications per month

until the deputy is free and can start working with the request.

The average time of waiting for being served by the $n$-channel QS $\mathrm{M} / \mathrm{M} / n$ is given by the following formula (Saati, 2010):

$$
T_{1}=\frac{1}{n \mu-\lambda}
$$

In Fig. 1 we give the dependence of the average time of waiting on the number of the serving "devices", that is, the number of the MPs receiving citizens. It is given for the intensity of the stream $\lambda=110$ applications per month and intensities of service $\mu$ equal to 2, 3 and 4 applications per month, respectively.

As can be seen from Fig. 1, for every value of service intensity there is a minimal number of working service "devices" necessary for supporting stable work of the system. Thus, with intensity $\mu=4$ applications per month it is necessary to have at least 28 working deputies. We may call this number a critical number $N_{c}$ of MPs. When the intensity of service reduces to 3 applications per month, stable work of the reception office is possible if the critical number of MPs $N_{c}=30$. Finally, with low intensity of service, when a separate MP proceeds two claims per month on average, for the stable work of the citizens' reception it is compulsory to have at least $N_{c}=60$ deputies participating in the work. But even in this case, as can be concluded by Fig. 1, the time of waiting for service will be about two weeks, which is evidently unacceptable.

We can see from Fig. 1 that near the critical value even slight changes of the number of service "devices" will lead to either a sharp increase in the time of waiting for service, or a sharp decrease in the time needed.

In case of a twofold increase in intensity of the applications' stream (up to 200 applications per month) compared to the intensity of the current stream of visitors, which is $\lambda=110$ applications per month, it is crucial to have at least 50 working MPs with any service intensity (Fig. 2).

The intensity of the applications' stream can be made lower using the queueing network where every application is served successively by two "devices" (Fig. 3). The first "device" (the expert 


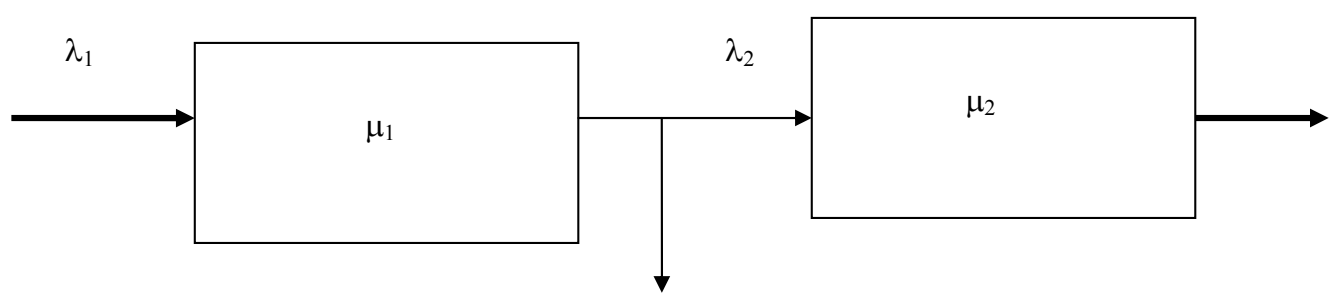

Fig. 3. The queueing network scheme modeling the process of citizens' applications reception in the RF State Duma public reception office of the United Russia faction

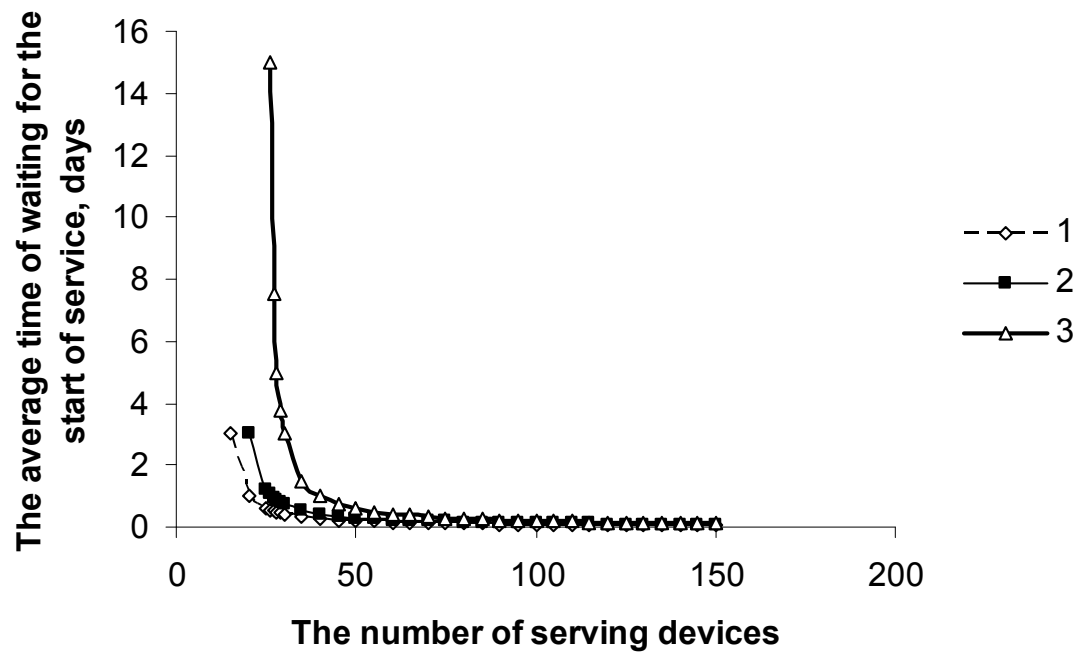

Fig. 4. The average time of waiting for the start of service with $\lambda=50$ applications per month; $1-$ intensity of $\mu=4$ applications per month; 2 - intensity of $\mu=3$ applications per month; 3 - intensity of $\mu=2$ applications per month

at the preliminary reception) determines the necessity for the application to be served by a MP and distributes the chosen applications for further service by a second "device" (MP).

Citizens with stream intensity $\lambda_{1}$ are received by an expert on the day of application, served with the intensity $\mu_{1}$ and either denied further service or directed to the next MP with intensity $\mu_{2}$. Here it is significant that the intensity $\lambda_{2}$ of the stream of applications to be served by MP is lower than the intensity $\lambda_{1}$ of the initial stream. It is such a QS that is used at present in the RF State Duma UR public reception office. The reception is held by the faction officials five days a week from 9.00 to 17.00. The average intensity of visitors' stream was 10 applications per day in 2012-2013 season.
However, the number increases as the elections to the State Duma or Presidential elections approach. Thus, in 2013-2014 the number of visitors increased up to 15 per day.

The two-stage service system allows making the stream intensity of incoming claims to the "devices" lower. In 2012-2013 the intensity of claims arrival to the deputies became about two times lower after the reception of the visitors by an expert who rejected service for part of the claims. Dependence of parameters of the average time of service waiting for all applicants to the public reception office who have passed both systems $\left(\mathrm{QS}_{1}\right.$ and $\left.\mathrm{QS}_{2}\right)$ on the number of MPs involved in reception of visitors is given in Fig. 4. 
As is seen from Fig. 4, with the two-stage QS being used participation of 40-50 deputies in the reception of visitors practically reduces the average time $T_{l}$ of waiting for service to 0 .

The curves in Fig. 1, 2 and 4 can be used as a kind of monograms for assessment of the critical number of MPs involved in the citizens' reception of depending on the assumed exogenous value of the average time $T_{1}$ of waiting for service. With reasonable value of $T_{1}=2$ days and $\lambda=50$ applications per month participation of 40 deputies is necessary.

In case of object service policy it is indispensable to sort out all applications by the given classification and to calculate the critical number of deputies receiving the citizens in each object group (Table 1).
With territorial service policy a certain problem will arise since nearly half of the citizens applying to the $U R$ public reception office are residents of only two subjects of RF Moscow and Moscow Region. In Table 2 we give information on applying to the RF State Duma $U R$ public reception office of residents from different regions of the Russian Federation.

Thus, the load on deputies from Moscow and Moscow Region will considerably exceed the load on deputies from other regions. It should be taken into account in choosing territorial service policy.

\section{Conclusion}

As is shown above, calculations with the QS allow assessing the efficiency of receiving citizens

Table 1. Subjects of citizens' applications to the public reception office of the RF State Duma UR faction in the 2012-2013 season

\begin{tabular}{|c|l|c|}
\hline Rank & \multicolumn{1}{|c|}{ Subjects } & Number of applications \\
\hline 1 & Human rights & 307 \\
\hline 2 & Housing and communal services & 158 \\
\hline 3 & Landed property and land use & 60 \\
\hline 4 & Applications for an audience & 58 \\
\hline 5 & Labour resources and employment & 58 \\
\hline 6 & Social security and Social insurance & 42 \\
\hline 7 & Work of bodies of self-government & 39 \\
\hline 8 & Health service & 38 \\
\hline 9 & Municipal and Road service & 30 \\
\hline 10 & Economy and banking system & 19 \\
\hline 11 & Lawmaking initiatives & 19 \\
\hline 12 & Culture, Physical culture & 16 \\
\hline 13 & Activities of political parties and public organizations & 13 \\
\hline 14 & Migration. Refugees and migrants & 13 \\
\hline 15 & Education. Science & 12 \\
\hline 16 & Industry, power engineering, construction & 8 \\
\hline 17 & Pension provision & 12 \\
\hline 18 & Social protection of armed-forces personnel and their families & 32 \\
\hline 19 & Family, maternity and childhood protection. Demography & 13 \\
\hline 20 & Religious questions & \\
\hline
\end{tabular}

These calculations are made similarly to the ones given above. 
Table 2. Applications of residents from different regions of the Russian Federation to the RF State Duma UR public reception office from September 1, 2012 to June, 30, 2013

\begin{tabular}{|l|c|c|}
\hline \multicolumn{1}{|c|}{ Federal District, region } & $\begin{array}{c}\text { Total number } \\
\text { of applications }\end{array}$ & $\begin{array}{c}\text { Intensity of applications stream } \\
\text { per month }\end{array}$ \\
\hline Far East District & 12 & 1.2 \\
\hline North Caucasus District & 44 & 4.4 \\
\hline Moscow Region & 186 & 18.6 \\
\hline Urals District & 25 & 2.5 \\
\hline Volga District & 84 & 8.4 \\
\hline Southern District & 48 & 4.8 \\
\hline Moscow & 420 & 42 \\
\hline North-western District & 42 & 4.2 \\
\hline Central District & 132 & 13.2 \\
\hline Siberian District & 51 & 5.1 \\
\hline Outside RF & 49 & 4.9 \\
\hline Total & 1093 & 109.3 \\
\hline
\end{tabular}

by RF State Duma Members and choosing the system of organizing official reception being optimal by the time spent on this procedure both by citizens and deputies. Besides, the proposed approach gives an opportunity to recognize the possibilities of considering applications in electronic form.

It is clear that in receiving applications via electronic nets the intensity of applications stream can be infinitely high. For preliminary calculations let us put the value of applications stream intensity equal to $\lambda=10^{4}$ applications per month, that is, only 100 times greater that it is at present. If the two-channel QS is used, part $P$ of the applications can be sifted out. But this value can be very large. When $P=0.99$, the mass media will promptly report uselessness of such applications. Suppose that in the electronic system value $P$ is supported close to the current value $P=0.50$. Then the stream of applications will have the intensity $\lambda=5^{*} 10^{3}$ applications per month. And for serving such a stream even at an extreme intensity $\mu=20$ (!) applications per month, the critical number of deputies must be approximately 250 . It is clear that in this case the deputies would not be able to do any other work.

Thus, the idea of receiving citizens' applications via electronic networks should be regarded at least with caution. The reception procedure currently used cannot work with such streams.

\section{References}

Gnedenko, V.V., Kovalenko, I.N. (2007). Vvedenie v teoriiu massovogo obsluzhivaniia [Introduction to Queueing Theory]. Moscow, URSS Publ., 400 p.

Federal'nyi zakon ot 8 maia 1994 № 3-FZ "O statuse chlenov Soveta Federatsii i statuse gosudarstvennoi Dumy [Federal Law of May, 8, 1994 № 3-FZ "On the Status of Members of the Federation Council and the State Duma of RF Federal Assembly].

Federal'nyi zakon ot 2 maia 2006 № 59-FZ “O poriadke obrashcheniia grazhdan Rossiiskoi Federatsii [Federal Law of May, 2, 2006 № 59-FZ "On the Procedure of the RF citizens Appellations]. 
Kleinrock, L. (1979). Teoriia massovogo obsluzhivaniia [The Queueing Theory]. Moscow, Izd-vo Mashinostroenie, $432 \mathrm{p}$.

Saati, T. (2010). Elementy teorii massovogo obsluzhivaniia $i$ ee prilozheniia [Elements of the Queueing Theory and its Applications]. Moscow, URSS Publ., 510 p.

Soukhovolsky, V.G., Shelekhov, A.M. \& Karpov, M.A. (2014). The organization of citizens' reception by Members of Russian Federation State Duma as Queueing Theory problem [Organizatsiia priema grazhdan deputatami gosudarstvennoi Dumi Rossiiskoi Federatsii kak zadacha teorii massovogo obsluzivaniia], In Tezisy simpoziuma "Slozhnye sistemy v ekstremal'nykh usloviiakh"[The abstracts of Symposium "The Complex Systems in Extreme Conditions]. Krasnoyarsk, p. 43.

Zakonodatel'nye akty perekhodnogo perioda. 1904 - 1908. [Legislative Acts of Transition Period. 1904-1908]. Moscow, 2010. P. 829.

\title{
Оптимизация процедуры приема граждан депутатами Государственной думы РФ
}

\author{
В.Г. Суховольскийа \\ М.А. Карпов \\ ${ }^{a}$ Сибирский федеральньий университет \\ Россия, 660041, Красноярск, пр. Свободный, 79 \\ ${ }^{\sigma}$ Тверской государственный университет \\ Россия, 170100, Тверь, Желябова, 33 \\ ${ }^{8}$ Ивановский государственный энергетический \\ университет \\ Россия, 153003, Иваново, Рабфаковская, 34
}

\begin{abstract}
Работа по приему граждан Российской Федераџии членами фракции «Единая Россия» Государственной думы РФ и проблема оптимизации процедуры приема рассматривается как задача теории массового обслуживания. С точки зрения теории массового обслуживания член парламента рассматривается как «прибор», обслуживающий поступаюшие требования. Простейшая система массового обслуживания $M / M / 1$ включает прибор (депутата) и поток требований граждан, поступающих с некоторой интенсивностью. Различные версии правил приема граждан обсуждаются в рамках теории массового обслуживания как различные дисцุиплины обслуживания. Эффективность приема граждан депутатами Госдумы вычисляется для различных дисичилин обслуживания. Такой подход позволяет выбрать систему организацчии персонального приема, оптимальную как для граждан, так и для депутатов.
\end{abstract}

Ключевые слова: граждане, депутаты, прием, оптимизация, модель, теория массового обслуживания.

Работа выполнена при финансовой поддержке РФФИ (грант № 13-07-00564-а).

Научная специиальность: 12.00.00 - юридические науки, 23.00.00- политология. 